\title{
Managerial Capabilities and Market Orientation in Mediating Entrepreneurial Orientation with Business Performance of Coffee Processing Smes in Pupuan
}

\author{
Made Putri Ariasih \\ Faculty of Economics and Business, Udayana University, Bali, Indonesia \\ Ni NyomanKerti Yasa \\ Faculty of Economics and Business, Udayana University, Bali, Indonesia \\ kertiyasa@unud.ac.id
}

Ketut Rahyuda

Faculty of Economics and Business, Udayana University, Bali, Indonesia

\begin{abstract}
Role analysis as well as the influence of managerial capabilities and market orientation in mediating entrepreneurial orientation with business performance on coffee processing SMEs in Pupuan and explaining the role of managerial capabilities and market orientation in mediating entrepreneurial orientation with business performance on coffee processing SMEs in Pupuan is the purpose of this study. The data of this research were collected through questionnaire method by using samples of 52 owners and managers in 26 units of coffee processing SMEs in Pupuan. Partial Least Square statistical analysis tool is used in this study and then tests the mediation effect. The result of this research concludes that managerial capabilities and market orientation have positive and significant influence and act as partial mediator between entrepreneurial orientation with business performance. The results also provide suggestions for continuously improving the high entrepreneurial attitude with managerial capabilities and market orientation to SMEs to be able to improve business performance.
\end{abstract}

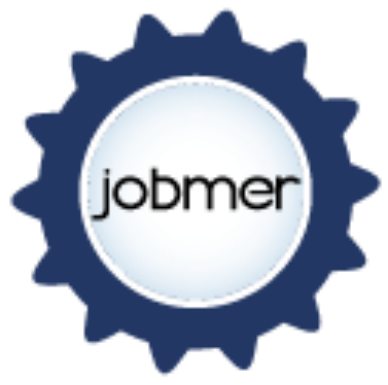

Journal of Business Management and Economic Research Vol.2, Issue.8, 2018 pp.1-12

Doi: 10.29226/TR1001.2018.53

Keywords: entrepreneurial orientation, managerial capabilities, market orientation, business performance, coffee processing.

\section{INTRODUCTION}

National economic growth is largely determined by the dynamics of the economy in areas sustained by small and medium sized economic activities, i.e. Small and Medium Enterprises (SMEs). SMEs play important roles in the regional and national economic and contribute substantial contributions in terms of increasing employment, reducing 
unemployment and distributing development outcomes throughout Indonesia (Nur et al., 2014). Therefore, SMEs have a very strategic role. The sustainability of an SME is certainly illustrated in its business performance. SMEs that have huge potential for export are coffee processing SMEs in Pupuan District, Tabanan Regency, Bali. However, this potential is not necessarily able to improve the performance of SMEs business. At this time SMEs processing coffee in Pupuan experiencing problems related to weak performance caused by problems in managerial and marketing aspects.

Suci (2009) states business performance as a series of work functions of a company within a certain period of time, which is reflected as the achievement of success or as a failure. Sales growth, asset growth and profit growth are used to measure business performance, especially the performance of small and medium business enterprises. The importance of the role of entrepreneurial orientation and its positive influence on business performance, is explained in several entrepreneurial researches e.g. Andersen (2010); Nur et al. (2014); Umar (2014) and Tricahyadinata et al. (2015). In the study of Hughes \& Morgan (2007) and Frank et al. (2010) show that entrepreneurial orientation indicators provide a negative significant relation to business performance.

The development of entrepreneurial orientation of SMEs is highly determined also by the managerial capabilities of the SMEs entrepreneurs themselves. The result of empirical study on the influence of managerial capabilities has been stated by Suci (2009), Maupa (2004) and Degravel (2011) which shows entrepreneurial orientation gives positive and significant influence on managerial capabilities. In other researches, it is stated that the research's result to influence of managerial capabilities is not significant to the performance, i.e. in research of Lo (2012), Umar (2014) and Nuret al. (2014). The study of Mithas et al. (2011) indicates that managerial capabilities has an important role in developing the company's capabilities. In addition, on the results of the study Umar (2014) and Nur et al. (2014) indicates a managerial capabilities capable of mediating well between the entrepreneurial orientation of business performance.

Market orientation is defined as the superior value created for the buyer to achieve higher business performance over competitors (Narver\& Slater, 1990). The market orientation consists of 3 indicators formed from the constructs, i.e.: customer orientation, competitor orientation and interfunctional coordination (Prakorsa, 2005). Previous researches which show negative relation between entrepreneurship orientation to business performance are by Hassim et al. (2011); Affendy et al. (2015); Matsuno et al. (2002); Pramesti \& Giantari (2016); Amin et al. (2016) found in the results of their researches that there is influence of mediation between entrepreneurial orientation to business performance of SMEs.

Therefore, the research on strategy management aims to identify the role of managerial capabilities and market orientation in mediating entrepreneurial orientation and business performance of coffee processing SMEs in Pupuan. The study also creates a hypothesis of relation between variables and testsevery hypotheses. Finally, we will discuss the implications of the findings in this study. 
Made Putri Ariasih - Ni NyomanKerti Yasa - Ketut Rahyuda, 2018, Vol.2, Issue.8, pp.1-12

\section{LITERATURE REVIEW}

\section{Entrepreneurial Orientation}

Hisrich et al. (2010) defines a state to be able to innovate to create something with new and different values as the process of entrepreneurial orientation. Lumpkin \&Dess (1996) states that the contribution of entrepreneurial orientation to the company is in the form of skill to innovate, risk-taking, and proactive behaviour. Lumpkin \& Dess (2001), Zahra \& Garvis (2000) and Wiklund \& Shepherd (2005) studies suggest that activities by small and medium-sized enterprises should be based on innovation, risktaking, and proactive behaviour to be better than their competitors.

\section{Managerial Capabilities}

Winardi (2005) defines managerial capabilities as a skill that aims to gain success over a defined goal, through planning, organizing, implementing and controlling. Latif (2002) argues that appropriate behavioural attitudes, motivations and abilities (skills) are important components in the application of managerial capabilities. In addition, Latif (2002) also states that indicator for managerial capabilities are indicator of verbal communication; managing time and demands in business; determining individual decisions; finding solutions to all problems; and giving encouragement to others.

\section{Market Orientation}

Orientation is defined as a balance between customer orientation and competitor orientation in marketing strategies to improve business performance (Narver\& Slater, 1990). Afsharghasemi et al. (2013) argues that a company must be able to apply market orientation to be one step ahead of competitors and provide added value for customers by of innovating.

The company can also improve its business performance by applying its attitude to maintain customer satisfaction and loyalty, gain new customers, and increase market share (Tsiotsou\&Vlachopoulou, 2011). Narver and Slater (1990) state the indicators of customer orientation, orientation towards competitorsand inter-functional coordination is used to measure market orientation in small and medium enterprises

\section{Business Performance}

Glancey et al. (1998) defines business performance as the highest achievement that a company can achieve within a given time period. Covin \& Slevin (1989) argue that in performance measurement procedures in small and medium industries are seen through three measurement indicators i.e. sales growth, asset growth and profit growth.

\section{RESEARCH HYPOTHESIS}

\section{Relations between entrepreneurial orientation with business performance}

High entrepreneurial orientation will provide the ability to gain new business opportunities that directly affects the company's earnings, which ultimately impact business performance positively (Keh et al., 2007). Research from Kreiser et al. (2002) demonstrates that indicators i.e. innovative, proactive and risk-taking are capable of 
Made Putri Ariasih - Ni NyomanKerti Yasa - Ketut Rahyuda, 2018, Vol.2, Issue.8, pp.1-12

improving performance in a company. Research from Nur et al. (2014) and Hassim et al. (2011) also shows that the relations between entrepreneurial orientations with business performance has a positive and significant relations. Hence, hypothesis $1 \mathrm{can}$ be stated as follows:

H1: The entrepreneurial orientation has a positive and significant impact on business performance.

\section{Relations of entrepreneurial orientation with managerial capabilities}

Entrepreneurship is a personal incentive to be able to acquire, manage and utilize existing resources. It will certainly encourage the increase in managerial capabilities which is more defined as the identification and control of self (Suci, 2009). Researches by Maupa (2004) and Degravel (2011) mention that the same results obtained where entrepreneurial orientation has a significant positive impact on its relations with managerial capabilities. Thus, hypothesis 2 can be stated as follows:

$\mathbf{H}_{2}$ : The entrepreneurial orientation has a positive and significant influence on managerial capabilities.

\section{Relations between entrepreneurial orientation with market orientation}

Gima \& Ko (2001) states that companies which aim to achieve better performance should be able to apply entrepreneurial orientation by considering market share, market entry and product quality (Gima \& Ko, 2001). Previous research by Riana (2010) suggests that entrepreneurial orientation is an important indicator in improving market orientation proactively. Previous researches on the relations between entrepreneurial orientation with market orientation which has a significant positive impact are explained by Vitale et al. (2002); Nur et al. (2014) and Pramesti \& Giantari (2016). Therefore, from the description above, hypothesis 3 can be stated as follows:

$\mathbf{H}_{3}$ : The entrepreneurial orientation has a positive and significant impact on market orientation.

\section{Relations between managerial capabilities with business performance}

Ability is a strong foundation to improve the business performance of a company by doing self-positioning according to the company's perspective (Degravel, 2011). The research by Suci (2009) shows that through good communication skills, appropriate problem solving, ability to manage pressure and time and ability to motivate others will be able to improve business performance. Researchesby Mithas et al. (2011) and Emadzade et al. (2012) also show that managerial ability is able to positively and significantly influence business performance. Thus, the hypothesis 4 proposed in this study is as follows:

$\mathbf{H}_{4}$ : Managerial capabilities has a positive and significant impact on business performance.

\section{Relations between market orientation with business performance}

A good business performance is strongly influenced and emphasized by the application of market orientations. The implementation of customer orientation, 
Made Putri Ariasih - Ni NyomanKerti Yasa - Ketut Rahyuda, 2018, Vol.2, Issue.8, pp.1-12

competitor orientation and inter-functional coordination significantly affect the improvement of business performance (Prakosa, 2005). Jaworski \& Kohli (1990) states that marketing of a company is more emphasized on market orientation in improving business performance. Researches from Riana (2010), Nur et al. (2014), Umar (2014) and Pramesti \& Giantari (2016) indicate that market orientation has a positive significant relationship to improving business performance. Hence, according to the results of previous researches, it can be stated hypothesis 5 in this study as follows.

$\mathbf{H}_{5}$ : Market orientation has a positive and significant impact on business performance.

Relations of managerial capabilities mediates entrepreneurial orientation with business performance

Managerial capabilities is very important in a business. A strong managerial base of planning, operational capability and good communication can improve business performance (Latif, 2002). An entrepreneurial orientation based on effective managerial skills is usually able to improve business performance in Small and Medium Enterprises (Neshamba, 2006). Previous research results from Duygulu \& Kurgun (2009); Suci (2009) and Degravel (2011) also show that entrepreneurial orientation has a positive and significant impact on business performance. Based on the previous empirical study above, hypothesis 6 can be proposed as follows:

$\mathbf{H}_{6}$ : The entrepreneurial orientation has a positive and significant impact on business performance through managerial capabilities.

Relations of market orientation mediates the entrepreneurial orientation with business performance

Entrepreneurial activities and marketing activities can be integrated to drive innovation within the company aimed at improving the business performance Gima et.al (2001). Olson (2010) states that an important concept in running an entrepreneurial orientation which aims to improve business performance is to be based on a strong market orientation. The previous empirical studies which proves that there is an indirect relationship between business performance where market orientation as a mediating variable are researches from Idar et al. (2012), Amin et al. (2016), Pramesti \& Giantari (2016) and Benito et al. (2007). Therefore, based on empirical studies above, hypothesis 7can be proposed as follows:

$\mathbf{H}_{7}$ : The entrepreneurial orientation has a positive and significant impact on business performance through market orientation.

From the description above of the literature hypotheses and research hypotheses, the concept of research framework is presented as shown below. 


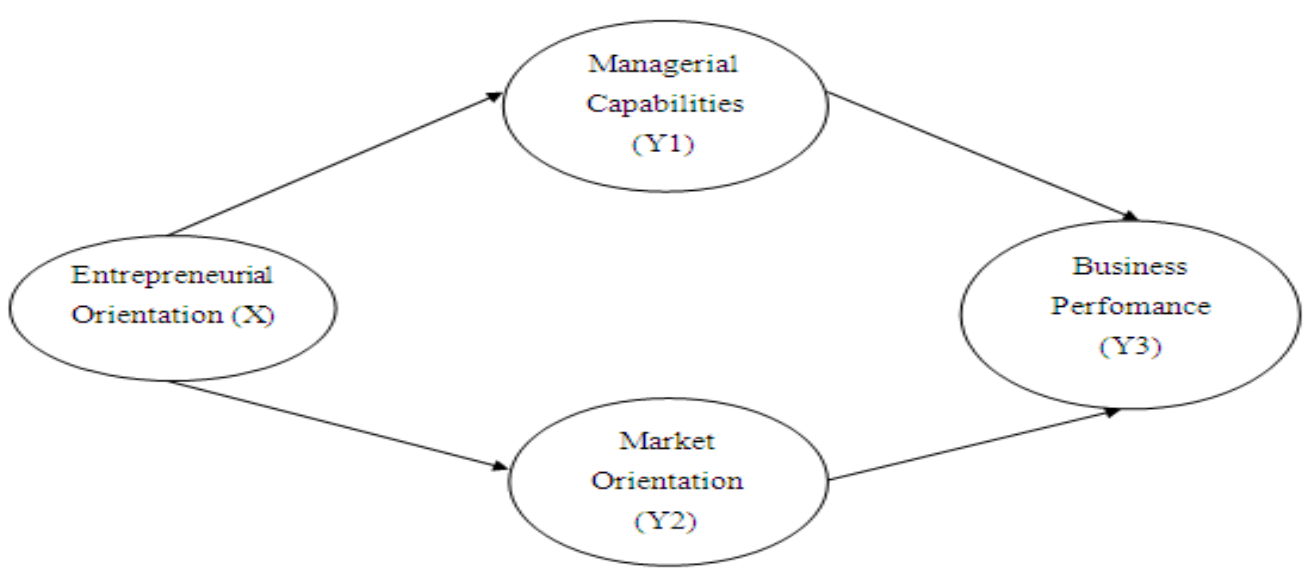

Picture 1. Conceptual Framework of Research

\section{RESEARCH METHOD}

The research is categorized as an explanatory research which see the relation between entrepreneurial orientation variables, managerial capabilities and market orientation on business performance. The data were collected by using survey method which is considered as the most appropriate or cross-sectional because it is very suitable to test the research hypothesis with data obtained at certain time range. The research is located in Pupuan District, Tabanan Regency. There search studies 26 units of coffee processing SMEs in Pupuan as population with owners and managers in SMEs processing coffee in Pupuan which has been established for at least 3 years as sample, so there were 52 respondents. SPSS 22.0 and Partial Least Square (PLS) are used because only small numbers of sample are studied.

\section{RESULTS}

Based on the survey, the results indicate that $73.07 \%$ coffee processing SMEs in Pupuan has established for 1-10 years with 1-5 workers. The workers in coffee processing SMEs in Pupuan (maximum 5 people) are dominated by male workers as much as $80.8 \%$ with the age of 38-47 years old and the highest education they have are at high school level. The results of the seven hypotheses showed a positive and significant influence. The test results are shown in Table 1 and Table 2 for the test of mediation effect. The result of the analysis on the influence of entrepreneurial orientation shows significant positive impact to business performance as evidenced by the significance value of 0,038 $<0,05$; hence hypothesis $\mathrm{H} 1$ is accepted, where entrepreneurial orientation gives significant positive impact to acceptable business performance.

The hypothesis that mentions entrepreneurial orientation has a positive significant effect on managerial capabilities and entrepreneurial orientation has a significant positive effect on market orientation shows the same significance value of $0.000<0.05$, therefore it is proven that hypotheses $\mathrm{H} 2$ and $\mathrm{H} 3$ are acceptable. 
Made Putri Ariasih - Ni NyomanKerti Yasa - Ketut Rahyuda, 2018, Vol.2, Issue.8, pp.1-12

Tabel 1. Path Coefficients

\begin{tabular}{|c|c|c|c|c|}
\hline Constructs & $\begin{array}{l}\text { Original } \\
\text { Sample }\end{array}$ & $\begin{array}{l}t \\
\text { Statistics }\end{array}$ & $p$ Values & Remarks \\
\hline $\begin{array}{l}\text { Entrepreneurial orientation } \quad(\mathrm{X}) \rightarrow \\
\text { Business performance }\left(\mathrm{Y}_{3}\right)\end{array}$ & 0,292 & 2,081 & 0,038 & Accepted \\
\hline $\begin{array}{l}\text { Entrepreneurial orientation }(\mathrm{X}) \rightarrow \\
\text { Managerial capabilities }\left(\mathrm{Y}_{1}\right)\end{array}$ & 0,770 & 12,283 & 0,000 & Accepted \\
\hline $\begin{array}{l}\text { Entrepreneurial orientation }(\mathrm{X}) \rightarrow \\
\text { Market orientation }\left(\mathrm{Y}_{2}\right)\end{array}$ & 0,737 & 8,543 & 0,000 & Accepted \\
\hline $\begin{array}{lll}\text { Managerial capabilities } & (\mathrm{Y} 2) & \rightarrow \\
\text { Business performance }\left(\mathrm{Y}_{3}\right) & & \end{array}$ & 0,299 & 2,241 & 0,025 & Accepted \\
\hline $\begin{array}{l}\text { Market orientation }(\mathrm{Y} 2) \rightarrow \text { Business } \\
\text { performance }\left(\mathrm{Y}_{3}\right)\end{array}$ & 0,382 & 2,838 & 0,005 & Accepted \\
\hline
\end{tabular}

The relation of managerial capabilities to business performance is indicated by the significance value of $0.025<0.05$ i.e. 0.025 , thus the hypothesis $\mathrm{H} 4$ is accepted. Likewise with $\mathrm{H} 5$ hypothesis that states the relation of market orientation to business performance where is indicated by the significance value of $0.005<0.05 \mathrm{~s}$, thus hypothesis $\mathrm{H} 5$ can beconsidered as significant or acceptable.

Tabel 2. Indirect Effects

\begin{tabular}{|l|l|l|l|l|}
\hline Construct & $\begin{array}{l}\text { Original } \\
\text { Sample }\end{array}$ & $\begin{array}{l}\boldsymbol{t} \\
\text { Statistics }\end{array}$ & $p$ Values & Remark \\
\hline $\begin{array}{l}\text { Entrepreneurial orientation }(\mathrm{X}) \rightarrow \\
\text { Business performance }\left(\mathrm{Y}_{3}\right)\end{array}$ & 0,512 & 5,353 & 0,038 & Accepted \\
\hline
\end{tabular}

The effect of indirect relation between entrepreneurial orientation and business performance shows significant positive result with coefficient value 0,512 . The $t$ statistics 5,353>critical t-value 1.96, which indicates the entrepreneurial orientation has indirect relation or through significant positive mediation variables on business performance through managerial capabilities variables and market orientation variables. Hence, $\mathrm{H} 6$ and $\mathrm{H} 7$ are proven and acceptable.

Tabel 3. Mediation Effect of Managerial Capabilities Test

\begin{tabular}{|l|l|}
\hline $\begin{array}{l}\text { Indirects Effect } \mathbf{0 , 7 7 0 * 0 , 2 9 9} \\
\text { (Entrepreneurial orientation } \rightarrow \text { Managerial capabilities =0,770; } \\
\text { Managerial capabilities } \rightarrow \text { Business performance =0,299) }\end{array}$ & 0,230 \\
\hline $\begin{array}{l}\text { Direct Effect Before Entering Mediating Variable } \\
\text { (Entrepreneurial orientation } \rightarrow \text { Business performance=0,544) }\end{array}$ & 0,544 \\
\hline $\begin{array}{l}\text { Total Effects } \\
\text { Variance Accounted For Method (VAF) Indirect Effect/Total Effect }= \\
0,230 / 0,774\end{array}$ & $\mathbf{0 , 3}$ \\
\hline
\end{tabular}


Table 3 shows the managerial capabilities of mediating the relation between entrepreneurial orientation and business performance score 0.3 or 30 percent and indicates that managerial capabilities as the partial mediator. This form of partial mediator explains that managerial capabilities is not the only mediator of entrepreneurial orientation relation on business performance of coffee processing SMEs in Pupuan but there are other mediator factors.

Tabel 4. Mediation Effect of Market Orientation Test

\begin{tabular}{|c|c|}
\hline 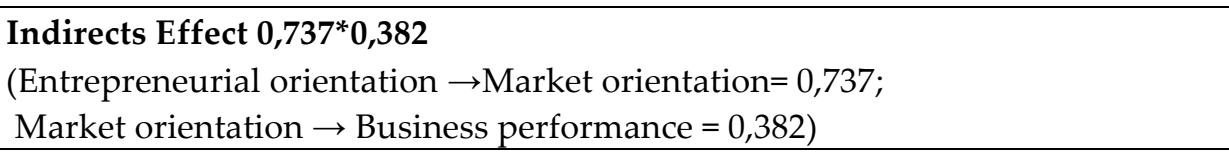 & 0,282 \\
\hline $\begin{array}{l}\text { Direct Effect Before Entering Mediating Variable } \\
\text { (Entrepreneurial orientation } \rightarrow \text { Business performance }=0,544)\end{array}$ & 0,544 \\
\hline $\begin{array}{l}\text { Total Effects } \\
\text { Variance Accounted For Method }(\mathrm{VAF})=\text { Indirect Effect/Total Effect = } \\
0,282 / 0,826\end{array}$ & $\begin{array}{l}0,826 \\
\mathbf{0 , 3 4}\end{array}$ \\
\hline
\end{tabular}

Table 4 shows the result of calculations test of mediation effect on market orientation where market orientation as a partial mediator between relations of the entrepreneurial orientation on business performance is 0.34 or 34 percent. These result illustrates that market orientation only mediates the relation between entrepreneurial orientation partially and business performance is one of the few factors that mediate the relation between entrepreneurial orientation with the performance business of coffee processing SMEs in Pupuan.

\section{DISCUSSION AND CONCLUSION}

The entrepreneurial orientation has a positive and significant impact on business performance. It means the higher the innovative, proactive and risk-taking values applied by the owners and managers of coffee processing SMEs in Pupuan, the more business performance will increase in coffee processing SMEs. It also supports researches from Kreiser et al. (2002); Nur et al. (2014) and Hassim et al. (2011).

The entrepreneurial orientation gives positive and significant influence to managerial capabilities. It means the higher the values of entrepreneurship orientation applied by the owners and managers of coffee processing SMEs in Pupuan, it will also increase the managerial capabilities of owners and managers of coffee processing SMEs in Pupuan, this also supports previous researches conducted by Suci (2009); Maupa (2004) and Degravel (2011).

The entrepreneurial orientation gives positive and significant influences to market orientation. It means the better the innovative, proactive and bold values of implementing the market orientation of coffee processing SMEs in Pupuan, the more market orientation of coffee processing SMEs in Pupuan. This also support of previous researches by Nur Et al. (2014); Vitale et al. (2002) and Pramesti \& Giantari (2016).

Managerial capabilities gives positive and significant influence to business performance. It implies the better the values of managerial capabilities in communication, determining personal decisions, motivating employees, and managing 
problems properly applied by the owners and managers coffee processingSMEs in Pupuan, it will also increase the business performance of coffee processing SMEs in Pupuan, It also supports the research conducted by Mithas et al. (2011), Sacred (2009), Degravel (2011), Emadzade et al. (2012).

Market orientation has a significant positive impact on business performance. This indicates that the better the values of customer orientation, to competitors and interfunctional coordination applied by the owners and managers of coffee processing SMEs in Pupuan, it will also increase the business performance ofcoffee processing SMEs in Pupuan. Iit also supports researches conducted by Nur et al. (2014), Umar (2014) and Pramesti \& Giantari (2016).

The managerial capabilities shows the skill to mediate partially. Through managerial capabilities, the relation of entrepreneurial orientation has a significant positive impact on business performance. This indicates that the higher the innovative, proactive and risk-taking values applied by the owners and managers of coffee processing SMEs in Pupuan through direct or mediated managerial capabilities, it will also increase business performance on coffee processing SMEs in Pupuan. It supports the research conducted by Latif (2002); Duygulu\&Kurgun (2009) and Degravel (2011).

The market orientation indicates being able to mediate partially. Through market orientation, the relation of entrepreneurial orientation provides a positive and significant impact on business performance. It indicates that the higher the innovative, proactive and risk-taking values applied by the owners and managers of coffee processing SMEs in Pupuan through direct or mediated market orientation, it will also increase business performance on coffee processing SMEs in Pupuan. It also supports the research conducted by Benito et al. (2007), Osman et al. (2011), Amin et al. (2016), Pramesti \& Giantari (2016).

\section{LIMITATIONS AND FUTURE RESEARCH}

The study also has limitations where this research is only done in a certain time point (cross section), while the environment can change at any time dynamically and the scope of research is only done on coffee processing SMEs located in Pupuan District, Tabanan Regency. Hence the results of this study cannot be generalized to coffee processing SMEs outside Pupuan District.

According tot the results of the research that has been obtained, suggestions that can be given to SME owners and managers to focus more and emphasize these dominant indicators without forgetting to improve weak indicators in order to improve overall business performance. Efforts to support the development of coffee processing SMEs in Pupuan District there must be synergies and proactive actions between local government and community in Pupuan District in particular as the key to success in improving business performance.

Second, the advice for academics is that future research needs to be considered to use another constructs, i.e. the skill of technological innovation that can mediate between the enterpreneurial orientation to business performance. In addition, enterpreneurial orientation can be positioned as the mediation between managerial capabilities and 
Made Putri Ariasih - Ni NyomanKerti Yasa - Ketut Rahyuda, 2018, Vol.2, Issue.8, pp.1-12

business performance. Future research may also extend research orientation within a wider range of populations and conduct research on different types of SMEs in other areas, hence the findings of this study may be different than those in other areas.

\section{REFERENCES}

Affendy, A.H., Asmat, N., Abdul, T. \& Farid, M.S., (2015). Entrepreneurial Orientation Effects on Market Orientation and SMEs Business Performance A SEM Approach. Review of Integrative Business E Economics Research, Vol. 4, No.3, pp.259-71.

Amin, M., Thurasamy, R., Aldakhil, A.M. \& Bin Kaswuri, A.H., (2016). The effect of market orientation as a mediating variable in the relationship between entrepreneurial orientation and SMEs performance. Nankai Business Review International, Vol.7, No.1, pp.39-59.

BPS Provinsi Bali., (2016). Berita Resmi Statistik Provinsi Bali: Pertumbuhan ProduksiI Industri Manufaktur Provinsi Bali. [Online] Badan Pusat Statistik Provinsi Bali Available at: https://bali.bps.go.id/Brs/view/id/185 [Accessed 22 November 2016].

Benito, O.G., Benito, J.G. \& Gallego, P.A.-M., (2009). Role Of Entrepreneurship And Market Orientation In Firms' success. European Journal of Marketing, Vol.43, No.3/4, pp.500-22.

Covin, J.G. \& Slevin, D.P., (1989). Strategic Management Of Small Firms In Hostile And Benign Environments. Strategic Management Journal, Vol.10, pp.75-87.

Covin, J.G. \& Slevin, D.P., (1991). A Conceptual Model Of Entrepreneurship As Firm Behavior. Entrepreneurship Theory and Practice, Vol.16, pp.7-25.

Degravel, D., (2011). Managing organizational capabilities: the Keystone step. Journal of Strategy and Management, Vo.4, No.3, pp.251-74.

Duygulu, E. \& Kurgun, A., (2009). The Effect Of Managerial Entrepreneurship Behavior On Employee Satisfaction: Hospitality Managers' Dilemma. African Journal of Business Management, Vol.3, No.11, pp.715-26.

Emadzade, M.A., (2012). Knowledge Management Capabilities and Organizational Performance. Interdisciplinary Journal of Contemporary Research in Business, Vol.3, No.11.

Frank, H., Kesseler, A. \& Fink, M., (2010). Entrepreneurial Orientation and Business Performance - A Replication Study. SBR, pp.175-98.

Gima, K.A. \& Ko, A., (2001). An Empirical Investigation of the Effect of Market. Organization Sciene, Vol.12, No.1, pp.54-74.

Glancey, K., Greig, M. \& Pettigrew, M., (1998). Entrepreneurial dynamics in small business service firms. Entrepreneurial Behaviour \& Research, Vol.4, No.3, pp.24968 .

Hassim, A.A., Nizam, A., Talib, A. \& Abu Bakar, A.R., (2011). The Effects of Entrepreneurial Orientation on Firm Organisational Innovation and Market 
Made Putri Ariasih - Ni NyomanKerti Yasa - Ketut Rahyuda, 2018, Vol.2, Issue.8, pp.1-12

Orientation Towards Firm Business Performance. 011 International Conference on Sociality and Economics Development, Vol.10, pp.280-84.

Hisrich, R.D., Peters, M.P. \& Shepherd, D.D., (2010). Entrepreneurship. 8th ed. New York: McGraw-Hill.

Hughes, M. \& Morgan, R.E., (2007). Deconstructing the relationship between entrepreneurial orientation and business performance at the embryonic stage of firm growth. Industrial Marketing Managemen, Vol.36, pp.651-61.

Idar, R., Yusoff, Y. \& Mahmood, R., (2012). The Effect of Market Orientation as Mediator to Strategic Planning Practices and Performance Relationship: Evidence from Malaysian SMEs. Procedia Economics and Finance, Vol.4, pp.68-75.

Jaworski, B.J. \& Kohli, A.K., (1993). Market orientation: Antecedents and Consequences. Journal of Marketing, Vol.57, pp.53-70.

Keh, T.H., Nguyen, T.T.M. \& Ng, H.P., (2007). The Effects Of Entrepreneurial Orientation And Marketing Information On The Performance Of SMEs. Journal of Business Venturing, Vol.22, pp.592-611.

Kreiser, P.M., Marino, L.D. \& Weaver, K.M., (2002). Assessing the psychometric properties of the entrepreneurial orientation scale: a multi-country analysis. Entrepreneurship: Theory and Practice, Vol.26, No.4, pp.71-95.

Latif, D.A., (2002). Model for Teaching the Management Skills Component of Managerial Effectiveness to Pharmacy Students. American Journal of Pharmaceutical Education, Vol.66, pp.377-80.

Lo, Y.H., (2012). Managerial Capabilities, Organizational Culture and Organizational Performance: The resource-based perspective in Chinese lodging industry. The Journal of International Management Studies, Vol.7, No.1, pp.151-57.

Lumpkin, G.T. \& Dess, G.G., (1996). Clarifying The Entrepreneurial Orientation Construct And Llinking It To Performance. The Academy of Management Review, Vol.21, No.1, pp.135-72.

Matsuno, K., Mentzer, J.T. \& Ozsomer, A., (2002). The Effect of Entrepreneurial Proclivity and Market Orientation on Business Performance. Journal Of Marketing, Vol.66, No.3, pp.18-32.

Maupa, H., (2004). Faktor-faktor yang Menentukan Pertumbuhan Usaha Kecil di Sulawesi Selatan. Disertasi Program Pascasarjana UNHAS.

Narver, J.C. \& Slater, S.F., (1990). The Effect of Market Orientation on Business Profitability. Journal of Marketing, pp.20-35.

Nur, N., Surachman, Salim, U. \& Djumahir, December (2014). Entrepreneurship Orientation, Market Orientation, Business Strategy, Management Capabilities On Business Performance; Study At Small And Medium Enterprise Printing In Kendari. International Journal of Business and Management Invention, Vol.3, No.12, pp.08-17. 
Made Putri Ariasih - Ni NyomanKerti Yasa - Ketut Rahyuda, 2018, Vol.2, Issue.8, pp.1-12

Olson, D.E., (2010). The Role Of Entrepreneurial Personality Characteristics On Entry Decision In A Simulated Market. USASBE/SBIDA, pp.1-13.

Osman, M.H.M., Ahmad, F.S. \& Rashid, M.A., (2011). Assimilating Entrepreneurial Orientation And Market Orientation Dimensions In The Context Of WomenOwned Small And Medium Sized Businesses. African Journal of Business Management, Vol.5, No.14, pp.5974-83.

Prakosa, B., (2005). Pengaruh Orientasi Pasar, Inovasi dan Orientasi Pembelajaran Terhadap Kinerja Perusahaan untuk Mencapai KeunggulanBersaing (Studi Empiris pada Industri Manufaktur di Semarang). Jurnal Studi Manajemen dan Organisasi, Vol.2, No.1, pp.35-57.

Prakosa, B., (2005). Pengaruh Orientasi Pasar, Inovasi dan Orientasi Pembelajaran Terhadap Kinerja Perusahaan untuk Mencapai KeunggulanBersaing (Studi Empiris pada Industri Manufaktur di Semarang). Jurnal Studi Manajemen dan Organisasi, Vol.2, No.1, pp.35-57.

Pramesti, N.M.V. \& Giantari, I.G.A.K., (2016). Peran Orientasi Pasar Memediasi Pengaruh Orientasi Kewirausahaan Terhadap Kierja UKM Industri Kerajinan Endek. E-Jurnal Manajemen Unud, Vol.5, No.9, pp.5754-5782.

Smart, D.T. \& Conant, J.S., (1994). Entrepreneurial Orientation, Distinctive Marketing Competencies and Organization Performance. Journal Of Applied Business Research, Vol.10, No.3, pp.28-38.

Suci, R.P., (2009). Peningkatan Kinerja Melalui Orientasi Kewirausahaan, Kemampuan Manajemen, dan Strategi Bisnis (Studi pada Industri Kecil Menengah Bordir di Jawa Timur). Jurnal Manajemen Kewirausahaan, Vol.11, No.1, pp.1-13.

Tricahyadinata, I., Hamzah, D., Taba, M.I. \& Hamid, N., (2015). The Relationship Between Entrepreneurship Orientation, 4as, And Servmo To Hotel Perfomance Study of Hotel Perfomance in East Kalimantan, Indonesia. Journal of Research in Business and Management, Vol.3, No.9, pp.22-35.

Tsiotsou, R.H. \& Vlachopoulou, M., (2011). Understanding the effects of market orientation and e-marketing on service performance. Marketing Intelligence $\mathcal{E}$ Planning, Vol.29, No.2, pp.141-55.

Umar, Z.A., (2014). Peran Kemampuan Manajemen dan Orientasi Pasar sebagai Mediasi Pengaruh Orientasi Kewirausahaan terhadap Kinerja Bisnis (Studi pada Industri Kecil dan Menengah Pangan di Gorontalo). Disertasi yang Dipublikasi. Universitas Gorontalo.

Vitale, R., Giglierano, J. \& Miles, M.P., (2004). An Exploratory Study of Selfadministrated Quck-audits as a Management Diagnostic to Assess Marketing and Entrepreneurial Orientations in Established and Startup Firms. ournal of Research in Marketing and Entrepreneurship, Vol.6, No.1, pp.64-77.

Wiklund, J., (1999). The Sustainability of the Entrepreneurial Orientation Performance Relationship. Entrepreneurship Theory and Practice, Vol.24, pp.37-48. 